\title{
Karaman İli Potansiyel Evapotranspirasyon Tahmini
}

\author{
Soner Çağatay BAĞÇACl'* (ID) Nermin ȘARLAK' (iD)
}

'Karamanoğlu Mehmetbey Üniversitesi, İnșaat Mühendisliği Bölümü, Karaman

Sorumlu yazar e-posta (Corresponding author e-mail): scbagcaci@kmu.edu.tr

Geliș tarihi (Received): 11.10.2017

Kabul tarihi (Accepted): 11.07.2019

DOI: $10.21657 /$ topraksu.654742

Öz

Dünyada tarım arazilerinin sulama planlamaları, terleme yoluyla bitki su tüketimleri ve buharlașma miktarlarını göz önünde bulunduran su bütçesi hesaplamalarıyla yapıımaktadır. Bitki kaplı alanlarda meydana gelen söz konusu buharlașma ve terleme olaylarının toplamı, hidrolojik çevrimin ölçülmesi en zor bileșeni olan evapotranspirasyonu meydana getirmektedir. Evapotranspirasyonun, belli referans bitki örtüleri, su alma ve büyüme koșulları varsayımlarındaki potansiyel değerleri, pek çok araștırmacı tarafından geliștirilen ampirik yöntemler ile tahmin edilebilmektedir. Bunların en bașında gelen FAO56 PenmanMonteith (FAO56 PM), güçlü teorik alt yapısı ve tahminlerinin güvenilirliği bakımından, tüm dünyada en yaygın olarak kullanılan referans potansiyel evapotranspirasyon (PET) tahmin yöntemi haline gelmiștir. Güvenilir tahminlerine karșın, FAO56 PM'nin, PET tahminlerinde çok fazla meteorolojik gözlem verisine intiyaç duyması ve karmașık hesaplama adımları, daha az gözlem verisi gerektiren tahmin yöntemlerini kullanmamızı zaruri kılabilmektedir. Bu çalıșmada, Konya Kapalı Havzası́nda yer alan ve önemli tarımsal faaliyetler gerçekleștiren Karaman ili potansiyel evapotranspirasyon miktarları FAO56 PM ile günlük, Turc (TC), Makkink (MK), Priestley Taylor (PT), Jensen Haise (JH), Hargreaves Samani (HS), Blaney Criddle (BC), Thornthwaite (TH) gibi FAO56 PM'ye kıyasla daha az ölçülmüș veri intiyacı olan ve kullanımı nispeten daha basit yedi farklı ampirik yöntemle ise aylık zaman adımlarında hesaplanmıștır. FAO56 PM günlük tahminlerinin toplanmasıyla elde edilen aylık PET değerleri, diğer PET tahmin yöntemleriyle elde edilen aylık değerlerle karșılaștıııımıștır. Sonuç olarak, çalıșmaya dâhil edilen yedi PET tahmin yönteminden, Turc, FAO56 PM ile 0.97'lik korelasyon (R2) ve 16.94 mm'lik (aylik) ortalama hata karelerinin karekökü (RMSE) değerleri ile en uyumlu sonucu vermiștir. Turc metodu uygun bir kalibrasyon yapılması durumunda Karaman ili özelinde önerilebilir bulunmuș ve geri kalan yöntemlerin uygulanabilirliği tartıșılmıștır.

Anahtar Kelimeler: Hidrolojik çevrim, FAO56 Penman Monteith, Karaman, potansiyel evapotranspirasyon

\section{Estimation of Potential Evapotranspiration in the Karaman Province}

\begin{abstract}
Irrigation scheduling is performed with the water budget calculations considering the plant water consumption by transpiration and evaporation, at the farmlands around the world. Sum of these transpiration and evaporation events which takes place at the plant covered areas, composes evapotranspiration which is the hardest components of the hydrological cycle to measure. The potential values of evapotranspiration, under assumptions as certain reference plant cover, watering and growing conditions, can be estimated with empirical methods developed by many researches. At the top of them, FAO56 Penman-Monteith (FAO56 PM) is widely used reference potential evapotranspiration
\end{abstract}


estimation (PET) method worldwide through its strong theoretical background and reliability of estimation.Despite of its reliable estimation, complicated calculation steps and requirement of various observed meteorological data impel us to use more practical PET estimation methods which require more easily findable meteorological data. In this study, the potential amounts of evapotranspiration, occuring in the Karaman province located in the Konya Closed Basin where advanced agricultural activities are carried out, were calculated by FAO56 PM method with daily time steps and by Turc (TC), Makkink (MK), Priestley Taylor (PT), Jensen Haise (JH), Hargreaves Samani (HS), Blaney Criddle (BC), Thornthwaite (TH) methods with monthly time steps. The monthly PET values were obtained by summing of daily estimations of FAO56 PM and then compared with the monthly PET values estimated by other empirical methods. As a conclusion, among seven PET estimation methods, Turc yielded most compatible results in comparison with FAO56 PM by 0.97 correlation coefficient value (R2) and $16.97 \mathrm{~mm}$ (monthly) root mean square error (RMSE) value. Turc was recommended with convenient calibration and remained methods were discussed.

Keywords: FAO56 Penman Monteith, hydrological cycle, Karaman, potential evapotranspiration

\section{GíRiș}

Tarım arazilerinin doğru sulama programlarının belirlenebilmesi için söz konusu bitkinin ne zaman ve ne kadar suya ihtiyacı olduğunun bilinmesi gerekir. Bitkinin tarla koșullarında intiyaç duyduğu su, bitki su tüketimi olarak ifade edilmektedir ve evapotranspirasyon miktarına eșit olduğu varsayılımaktadır. Hidrolojik çevrim parametrelerinden belirlenmesi en zor olan evapotranspirasyon, bitki örtüsü bulunan bir alandan kaybolan toplam su miktarı olarak tanımlanmaktadır. Evapotranspirasyonun geniș alanlarda ölçülmesi maddi olarak çok büyük yük teșkil etmekle birlikte, küçük ölçeklerde ölçüm yapmak mümkündür. Arazi ölçeğinde evapotranspirasyon miktarları, su dengesi prensibine dayanan lizimetre düzenekleri, ortamdaki su buharının türbülanslı rüzgârlar ile tahliyesinin sensörler yardımıyla takip edilmesi esasına dayanarak geliștirilmiș eddykovaryans yöntemi, bowen oranı enerji dengesi ve buharlașma tavaları kullanılarak ölçülebilmektedir (Dingman, 2008; Akpolat, 2011; Abdulkareem vd., 2015). Son zamanlarda ayrıca gelișen uydu teknolojisiyle birlikte, uzaktan algılama yöntemleriyle de havza bazında evapotranspirasyon miktarlarının tahmini üzerine çalıșmalar bulunmaktadır (Zang vd., 2010; Lingling vd., 2013; Aksu ve Arıkan, 2017). Bu yöntemlerin yanı sıra özellikle son 60-70 yıl içinde maliyetinde ve uygulanmasında herhangi bir yük olmayan ve meteorolojik gözlem verilerinin fiziksel bazlı birtakım denklemlerde kullanılarak, PET tahmin edilmesine dayanan ampirik yöntemler geliștirilmiștir (Alexandris vd., 2008). Bu amaçla geliștirilen yaklașık 50 PET tahmin yöntemi bulunmasına rağmen, bu yöntemlerin farklı iklim koșullarına daha fazla uygunluk göstermesi ve intiyaç duyduğu meteorolojik gözlem verilerinin farklı olması gibi sebeplerle aynı bölge için uygulandıklarında dahi farklı sonuçlar verebilmektedirler (Grismer vd., 2002). Söz konusu ampirik tahmin yöntemlerinden BC sadece tek bir meteorolojik gözlem verisine intiyaç duyarken, FAO56 PM gibi kombinasyon yöntemleri çok daha karmașıktır ve PET tahmininde çok daha fazla meteorolojik değișkenin kullanılmasıını gerektirmektedir.

Evapotranspirasyon konusunda geçmișten günümüze kadar pek çok çalıșma yapılmıștır. Bu çalıșmada, son yillarda deneysel çalıșmalardan gözlemledikleri veya FAO56 PM (Allen vd., 1998) ampirik yöntemi ile diğer ampirik yöntemleri kıyaslayarak, çalıșma alanları için en iyi tahmin yapan ama aynı zamanda daha az değișkene intiyaç duyan tahmin yöntemini önerme kaygısı tașıyan çalıșmaların bazılarına yer verilmiștir. Lu vd. (2005), Amerika Birleșik Devletleri'nin güneydoğusunda yer alan sıcak ve nemli iklim koșullarına sahip 36 ormanla kaplı havza için yaptıkları çalıșmada, ampirik yöntemlerle hesapladıkları PET değerlerini, su dengesi yöntemiyle hesapladıkları gerçek evapotranspirasyon değerleri ile karșılaștırmıșlardır. PT, TC ve Hamon (1961) ampirik yöntemlerini, daha az gözlem verisi gerektirdiği ve gerçek evapotranspirasyon değerleriyle daha uygun korelasyon sağladığı için önerilebilir bulmușlardır. Ölçülmüș global güneș radyasyonunun mevcut olduğu durumlarda ise PT yönteminin en iyi PET tahmini yapan yöntem olduğunu ifade etmișlerdir. Alexandris vd. (2008), Sırbistan'ın merkezinde yer alan yağmur suyuyla beslenen çimle kaplı deney 
sahası için yaptıkları çalıșmada, FAO56 PM ile MK, TC, PT, HS, Copais (2006), Alexandris vd., (2006) ve modifiye Hargreaves Trajkovic, 2007 ampirik yöntemlerini karșılaștırmalı olarak incelemișler ve günlük verilerle $\mathrm{FAO56}$ PM yöntemine en yakın sonuçların PT ve Copais yöntemleri tarafından verildiğini tespit etmișlerdir. Tabari (2010), FAO56 PM ile tahmin ettiği PET değerlerini referans olarak kabul ettiği çalıșmasında, İran'da farklı iklim özelliklerine sahip bölgelerde yer alan on iki meteorolojik gözlem istasyonundan aldığı verileri kullanmıștır. Buna göre soğuk nemli ve kurak bölgelerde en uyumlu sonuçları TC, sıcak nemli ve yarı kurak bölgelerde en uyumlu sonuçları HS'nin verdiğini, kıyaslama yaptığı diğer MK ve PT yöntemlerinin ise genel olarak düșük performans gösterdiğini ifade etmiștir. Tukimat vd. (2012), Malezya'nın Kedah eyaletinde, ortalama sıcaklığın 27-32 ${ }^{\circ} \mathrm{C}$, rölatif nemliliğin ise \%54-94 arasında değișen sulama alanları için yaptıkları PET tahmini çalıșmasında, FAO56 PM ile TC, MK, PT, TH, BC ve HS yöntemlerini karșılaștırmıșlardır. Genel olarak bölge için radyasyon bazlı olan MK, TC ve PTyöntemlerinin, sıcaklık bazlı olan $\mathrm{TH}, \mathrm{BC}$ ve HS yöntemlerine göre daha iyi sonuçlar verdiğini, korelasyon katsayıları ve rölatif hatalar birlikte göz önüne alındığında ise MK en iyi, BC ise en kötü performansı göstermiștir. Fisher ve Pringle III (2013), Amerika'nın nemli iklim koșullarına sahip Mississippi bölgesinde yaptıkları PET tahmin çalıșmasında, FAO56 PM ile ölçülmüș veri intiyacı sadece hava sıcaklığına indirgenmiș FAO56 azaltılmıs set, TC ve Hargreaves yöntemlerini karșılaștırmıșlar ve bölge için en uygun yöntemin TC olduğunu iddia etmișlerdir. Efthimiou vd. (2013), Yunanistan'ın Batı Makedonya bölgesinde yer alan nemli iklim koșullarına sahip Krania ve Kozane meteorolojik gözlem istasyonlarından aldıkları uzun yillara ait verilerle, FAO56 PM ile tahmin ettikleri PET değerlerini FAO-24 Penman, MK, TC, Penman, PT, Linacre, Kimberly Penman, HS, Copais yöntemleriyle elde ettikleri PET değerleriyle karșılaștırmıșlardır. Global güneș radyasyonunu tüm yöntemler için ampirik denklemlerle elde ederek yaptıkları PET tahminlerinde, Krania gözlem istasyonunda FAO56 PM ile en iyi korelasyonu PT, Kozane gözlem istasyonunda ise TC olduğunu saptamıșlardır. Literatürde, Türkiye'de PET tahmin yöntemlerinin bölgeler özelinde karșılaștırmalı olarak tahmin edildiği bir çalıșmaya rastlanmamıștır.

Bu çalıșmada, Konya Kapalı Havzası́nda yer alan ve önemli tarımsal faaliyetler gerçekleștiren
Karaman ili PET miktarları FAO56 PM ile günlük, TH, MK, BC, TC, JH, PT, HS gibi FAO56 PM'ye kıyasla daha az ölçülmüș veri intiyacı olan ve kullanımı nispeten daha basit yedi farklı ampirik yöntemle ise aylık zaman adımlarında hesaplanmıștır. FAO56 PM günlük tahminlerinin toplanmasılyla elde edilen aylık PET değerleri diğer ampirik PET tahmin yöntemleriyle elde edilen aylık değerlerle karșılaștırılarak bölge özelinde yedi ampirik PET tahmin yöntemlerinin kullanılabilirliği tartıșılmıștır.

\section{MATERYAL VE YÖNTEM}

\section{Materyal}

Karaman ili kuzey, doğu ve batısında Konya, güneyinde Mersin ve güneybatısında Antalya illeri ile çevrilidir ve karasal iklim özellikleri gösterir. Çalıșma periyodu olan 2000-2015 yılları Mart-Kasım dönemi için Karaman ilinin toplam yağıș ortalaması 202 mm olup, yaz aylarında ortalama sıcaklıklar 22 ila $25^{\circ} \mathrm{C}$ arasında değișmektedir. Yine aynı dönemde Karaman ilinde aylık maksimum sıcaklık, $40.4^{\circ} \mathrm{C}$ ile 2000 yılının temmuz ve 2010 yılının ağustos ayında, aylık minimum sıcaklık ise $-21.2^{\circ} \mathrm{C}$ ile 2001 yılının kasım ayında ölçülmüștür. Çalıșma periyodu olan 2000-2015 yılları Mart-Kasım dönemi PET tahmin yöntemlerinde kullanılacak günlük minimum, maksimum ve ortalama sıcaklıklar $\left({ }^{\circ} \mathrm{C}\right)$, günlük toplam global güneș radyasyonu (cal/ $\left.\mathrm{cm}^{2}\right)$, günlük ortalama rüzgâr hızı $(\mathrm{m} / \mathrm{s})$, günlük ortalama nispi nem (\%), aylık minimum, ortalama ve maksimum sıcaklıklar $\left({ }^{\circ} \mathrm{C}\right)$, aylık toplam global güneș radyasyonu $\left(\mathrm{cal} / \mathrm{cm}^{2}\right)$ gözlem verileri Meteoroloji Genel Müdürlüğü'nün 17246 numaralı Karaman Meteorolojik Gözlem İstasyonundan $137^{\circ}$ $12^{\prime} \mathrm{K}, 33^{\circ} 13^{\prime}$ D, 1039 m) alınmıștır. Söz konusu dönemde günlük ortalama rüzgâr hızlarında 2012, 2013, 2014, 2015 yıllarında görülen eksik veriler sırasıyla \%15.6, \%21, \%17.4, \%38.9 oranlarında olduğu için bu yıllar çalıșmaya dahil edilmemiștir. Kullanılan ampirik PET tahmin yöntemleri hakkında özet bilgi așağıda sunulmuștur.

\section{Thornthwaite (TH)}

Bir bölgenin enleminin ve aylık ortalama hava sıcaklığının bilinmesi halinde rahatlıkla uygulanabilen bir PET tahmin yöntemi olup așağıdaki eșitlikler ile ifade edilmiștir (Thornthwaite, 1948):

$\mathrm{PET}=1.6 \mathrm{~L}_{d}\left(10 \mathrm{~T}^{-1}\right)^{\alpha}$

$\left.\alpha=6.75 \times 10^{-7} I^{3}-7.71 \times 10^{-5}\right) I^{2}+0.01791 I+0.49239 \quad$ (1a) 
$I=\sum_{j=1}^{12}\left(\frac{T_{j}}{5}\right)^{1.514}$

Eșitlikte; PET ( $\mathrm{cm}$ ay ${ }^{1}$ ); T aylık ortalama sıcaklık ( $\left.{ }^{\circ} \mathrm{C}\right)$, I aylara göre ortalama sıcaklığa bağı olan ısı indeksi, Ld saat olarak ortalama gündüz uzunluğudur.

\section{Blaney Criddle (BC)}

Potansiyel evapotranspirasyon tahminlerinde sadece ölçülmüș olarak ortalama sıcaklık verilerine intiyaç duyar. Kullanımı basit olmakla birlikte, çalıșmalar ekstrem hava koșullarında hesaplanan evapotranspirasyon tahminlerinin kușkulu olduğunu vurgulamaktadır. Rüzgârlı, kuru ve güneșli havalarda \%60'a kadar normalden așağı; soğuk, nemli ve bulutlu havalarda ise $\% 40$ oranında normalden yukarı tahminler yapabilen Blaney Criddle yönteminin en genel hali așağıda Eșitlik 2 . ile ifade edilmiștir (Blaney ve Criddle, 1950; http:// www.fao.org/docrep/s2022e/s2022e07.htm)

$\mathrm{PET}=p(0.46 \mathrm{~T}+8)$

Eșitlikte; PET (mm gün-1); T günlük ortalama hava sıcaklığı $\left({ }^{\circ} \mathrm{C}\right)$ ve $p$ enleme bağlı günlük gün ıșığı saatlerinin yıllık değere oranıdır.

\section{Makkink (MK)}

1957'de Hollanda'da, Penman yöntemi ile tahmin edilen evapotranspirasyon miktarlarının lizimetre ölçümleri ile kalibre edilmesiyle elde edilen Penman yönteminin uyarlanmıș halidir ve Eșitlik 3. ile ifade edilmiștir (Makkink, 1957; Allen, 1998; Xu ve Singh, 2000; Tabari, 2010; Zhai vd., 2010):

PET $=0.61 \Delta(\Delta+\gamma)^{-1} R_{s} \lambda^{-1}-0.012$

Eșitlikte; PET (mm gün-1); $R_{\mathrm{s}}$ kIsa dalga boyu radyasyon ( $\mathrm{MJ} \mathrm{m}^{-2}$ gün $\left.^{-1}\right) ; \Delta$ doygun buhar basıncı eğrisinin eğimi $\left(\mathrm{KPa}^{\circ} \mathrm{C}^{-1}\right)$; $\gamma$ psikometre sabiti ( $\mathrm{kPa}$ $\left.{ }^{\circ} \mathrm{C}^{-1}\right) ; \gamma$ buharlașma gizli ısısıdır (MJ kg ${ }^{-1}$ ).

\section{Turc (TC)}

Batı Avrupa'nın genel iklim koșullarında geliștirilmiș olup, evapotranspirasyon tahminlerinde ölçülmüș olarak rölatif nemlilik, ortalama sıcaklık ve global güneș radyasyonu verilerine intiyaç duyar (Turc, 1961; Xu ve Singh, 2000; Zhai vd., 2010; Tabari, 2010).

Eğer $\mathrm{RH}>50$ ise $\left.\mathrm{PET}=0.013 \mathrm{~T}(\mathrm{~T}+15)^{-1}\right) \quad(\mathrm{Rs}+50)$

Eğer $R H \leq 50$ ise $P E T=0.013 T(T+15)^{-1}\left(R_{s}+50\right)$ $\left(1+(50-\mathrm{RH}) 70^{-1}\right)$

Eșitliklerde; PET (mm gün-1); T ortalama günlük hava sıcaklığı $\left({ }^{\circ} \mathrm{C}\right)$; Rs kısa dalga boyu radyasyon $\left(\mathrm{MJ} \mathrm{m} \mathrm{m}^{-2}\right.$ gün $^{-1}$ ) ve RH rölatif nemliliktir (\%).

\section{Jensen Haise (JH)}

Jensen ve Haise evapotranspirasyon tahminini, 35 yıllık çalıșma periyodunda gözlemledikleri 3000 toprak numunesi üzerinden yaptıkları ölçümlerle elde ettikleri așağıdaki eșitlik ile yapmıșladır (Jensen ve Haise, 1963; Lingling vd., 2013):

$P E T=C_{t}\left(T-T_{x}\right) R_{s} \lambda^{-1} ; C_{t}=0.025 ; \quad T_{x}=-3$

Eșitlikte; PET (mm gün-1); Ct sıcaklık sabitidir.

\section{Priestley Taylor (PT)}

Orijinal Penman (1948) yönteminin kısaltılmıș halidir ve evapotranspirasyon tahminlerinde adveksiyon etkisininin oldukça küçük olduğu varsayımı üzerine bina edilmiștir. Priestley ve Taylor, Eșitlik 6. da görüldüğü gibi rüzgar hızını içeren aerodinamik etkiyi 1.26 katsayısına indirgemișlerdir (Priestley ve Taylor, 1972; Zhai vd., 2010; Tabari, 2010; Efthimiou vd., 2013):

$\mathrm{PET}=\alpha \Delta(\Delta+\gamma)^{-1} \quad\left(\mathrm{R}_{\mathrm{n}}-\mathrm{G}\right) \lambda^{-1} ; \alpha=1.26$

Eșitlikte; PET (mm gün-1 $)$; $R_{n}$ net radyasyon ( $\mathrm{MJ} \mathrm{m}^{-2}$ gün ${ }^{-1}$ ) ve $G$ toprak ısı akıșıdır ( $M ~ m^{-2}$ gün-1) (günlük ve daha büyük periyotlarda $\mathrm{G}=0$ kabul edilebiliyor).

\section{Hargreaves Samani (HS)}

Hargreaves'in (1975) orijinal evapotranspirasyon tahmin yöntemindeki solar radyasyon verileri yerine Hargreaves ve Samani (1982), ampirik denklemlerle bulunabilen uzay radyasyonu verilerini kullanarak ölçülmüș veri ihtiyacını sadece sıcaklığa indirgeyen bir PET tahmin yöntemi geliștirmișlerdir (Hargreaves ve Samani, 1985; Lu vd., 2005).

PET $=0.0023 R_{a}\left(T_{\text {max }}{ }^{-} T_{\min }\right)^{0.5}\left(T_{\text {ort }}+17.8\right) \lambda^{-1}$

Eșitlikte; PET ( $\left.\mathrm{mm}_{\text {gün}}{ }^{-1}\right)$; Ra uzay radyasyonu (MJ $\mathrm{m}^{-2}$ gün-1); Tmax maksimum günlük hava sıcaklığı ( $\left.{ }^{\circ} \mathrm{C}\right)$; Tmin minimum günlük hava sıcaklığı $\left({ }^{\circ} \mathrm{C}\right)$; Tort ortalama günlük hava sıcaklığıdır $\left({ }^{\circ} \mathrm{C}\right)$.

\section{FAO56 Penman Monteith (PM)}

PET tahmin yöntemleri içinde dünyada kullanımı en yaygın olanıdır ve ölçülmüș olarak günlük minimum, ortalama ve maksimum hava sıcaklığı, global güneș radyasyonu, ortalama rüzgâr hızı ve nispi nem verilerine ihtiyaç duyar (Allen vd., 1998). Bu yöntem; sıcaklık, radyasyon ve aerodinamik bileșenleri bünyesinde barındırdığı için karma yapıda bir PET tahmin yöntemidir ve Eșitlik 8. ile ifade edilmiștir:

Eșitlikte; PET (mm gün-1); $U_{2} 2 \mathrm{~m}$ yükseklikten ölçülen rüzgâr hızı $\left(\mathrm{m} \mathrm{s}^{-1}\right)$; es doygun buhar basıncı (kPa); ea gerçek buhar basıncıdır ( $\mathrm{kPa})$.

$P E T=\frac{\left(0,408\left(R_{n}-G\right)+900 \lambda(T+273)^{-1}\left(U_{2}\left(e_{s}-e_{a}\right)\right.\right.}{\Delta+\gamma\left(1+0,34 U_{2}\right)}$ 


\section{BULGULAR VE TARTIȘMA}
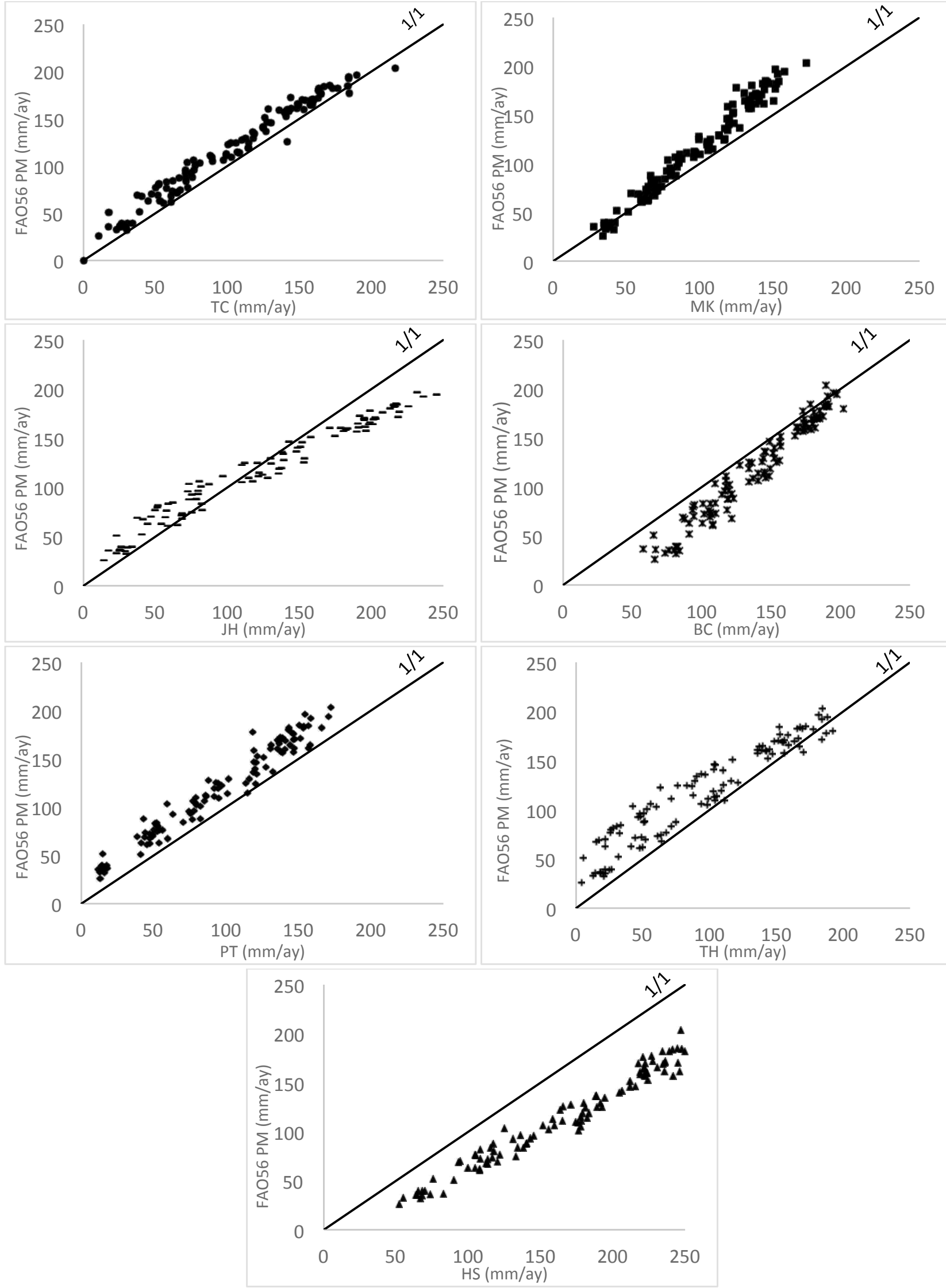

Sekil 1. Karaman ilinde FAO56 PM ve alternatif yöntemlerin aylık PET tahminleri

Figure 1. Estimation of monthly PET by FA056 PM and alternative methods in Karaman province 
2000-2011 yılları Mart-Kasım dönemi günlük meteorolojik verileri öncelikle homojenlik testine tabi tutulmuștur. İstasyon yerlerindeki veya ölçüm tekniklerindeki değișiklikler gibi veya istasyonun çevresindeki șehirleșme ve bina yüksekliklerinin artması vb. doğal olmayan nedenlerden dolayı ölçüm verilerinin homojenliği bozulabilmektedir. Homojen olmayan veriler sonuç üzerinde yanıltıcı etki olușturabileceğinden tespit edilmesi gerekmektedir. Standart normal (SNHT), Buishand sıra ve Pettitt homojenlik testleri ile günlük maksimum, minimum ve ortalama sıcaklıklar ve toplam global güneș radyasyon verilerinin \%5 anlam seviyesinde homojen oldukları, rüzgâr ve rölatif nem verilerinin homojen olmadıkları tespit edilmiștir. Söz konusu testler, homojenliği bozan veri setleri ve setlerin ortalama seviyeleri hakkında bilgi verdiklerinden, setlerin ortalama seviye oranları kullanılarak veriler homojen hale getirilmeye çalıșılmıștır (Tuomenvirta, 2001).

2000-2011 yılları Mart-Kasım dönemlerine ait günlük meteorolojik gözlem verileri kullanılarak FAO56 PM yöntemi ile PET tahminleri yapılmıs ve sonuçlar referans olarak kullanılmıștır. FAO56 PM ile tahmin edilen aylık PET miktarları, günlük tahminlerin toplamı șeklinde hesaplanmıș ve daha sonra aylık meteorolojik gözlem verileri kullanılarak diğer yedi ampirik yöntem ile tahmin edilen PET miktarları ile karșılaștırıımıștır. PET tahminleri, Thornthwaite hariç diğer yöntemlerde günlük meteorolojik gözlem verileri kullanılarak geliștirilmișlerdir. Ancak bölge için kullanımı daha basit, daha az meteorolojik gözlem verisine intiyaç duyan ve daha uzun zaman adımlı (aylık) PET tahminlerinde kullanılabilecek bir yöntemi Karaman ili için önermek maksadıyla hesaplamalar alternatif yöntemlerin hepsinde aylık meteorolojik gözlem verileri kullanılarak yapıımıștır. Bu kapsamda yapılan hesaplamalara ait sonuçlar Șekil 1'de görsel olarak sunulmuștur. Görsel olarak bakıldığında TC, MK, PT ve TH yöntemleri PET tahminleri çoğunlukla FAO56 PM tahminlerinden daha düșük, bunların aksine HS tahminleri daha yüksek olmuștur. BC 150 mm'ye kadar FAO56 PM'den yüksek tahminler verirken, 150 mm'den sonra yaz aylarına denk gelen PET tahminleri ise FAO56 PM ile yakındır. $\mathrm{JH}$ yönteminin ise yaklașık 120 mm'ye kadar olan PET tahminleri FAO56 PM'den düșük, 120 mm'den sonraki PET tahminleri ise FAO56 PM'den yüksek kalmıștır.

Yöntemler arasındaki istatistiksel karșılaștırma ortalama mutlak hata (MAE), ortalama hata karelerinin karekökü (RMSE) ve lineer model ile açıklanabilen yüzde (R2) ile yapılmıș ve çizelge

Çizelge 1. FAO56 PM ve diğer ampirik PET tahmin yöntemlerinin karșılaștırılması

Table 1. Comparison of FAO56 PM and the other empirical PET estimation methods

\begin{tabular}{cccc}
\hline Yöntemler & MAE & RMSE & $R^{\wedge} 2$ \\
\hline FAO56 PM-TC & 15.22 & 16.94 & 0.97 \\
FAO56 PM-MK & 18.54 & 22.37 & 0.97 \\
FAO56 PM-JH & 19.28 & 23.02 & 0.97 \\
FAO56 PM-PT & 20.57 & 24.30 & 0.95 \\
FAO56 PM-BC & 24.03 & 25.91 & 0.96 \\
FAO56 PM-TH & 24.83 & 29.51 & 0.91 \\
FAO56 PM-HS & 51.79 & 54.02 & 0.97 \\
\hline
\end{tabular}

1'de özetlenmiștir.

Uygun bir kalibrasyonla Turc metodunun vermiș olduğu $16.94 \mathrm{~mm}$ RMSE değerinin düșürülebileceği açıktır. MK yöntemi, TC'nin ardından FAO56 PM ile en yakın tahminleri yapan ikinci yöntem olmuștur. TC tahminleri gibi MK çalıșma döneminde çoğunlukla FAO56 PM'in altında tahmin vermiștir. JH üçüncü yöntem olurken, TH tüm dünyada olduğu gibi Karaman ilinde de FAO56 PM'nin oldukça gerisinde PET tahminleri verdiğinden beșinci sırada yer almıștır. HS ise Karaman ili için FAO56 PM'e en uzak tahmin veren yöntem olmuștur. 54.02 mm'lik ortalama hata karelerinin karekökü değeri diğer yöntemlerden elde edilen değerlerin iki katından fazladır. Bu çıkan sonuç aslında anlamlıdır, çünkü HS diğer yöntemlerin aksine net veya kısa dalga boyu radyasyon yerine uzay radyasyon verisini kullanmaktadır. Bunun anlamı atmosferin geçirgenliğini dikkate almadan maksimum olası radyasyon verileri ile PET tahmini yapılmaktadır. Ayrıca günlük meteorolojik gözlem verileriyle kullanıldığında HS'nin, California Davis bölgesi için oldukça makul PET tahminleri yaptığı ortaya konulmasına karșın, bu çalıșmada da olduğu gibi aylık meteorolojik gözlem verileriyle kullanıldığında yüksek hatalar vermesinin bir diğer sebebi olarak, günlük ve aylık maksimum, minimum sıcaklık ölçüm farklılığı gösterilebilir. HS metoduna karekökü çarpan olarak etkileyen maksimum ve minimum sıcaklıklar arasındaki farklar günlük verilerle kullanıldığında kullanılan gün için ölçülen maksimum ve minimum 
sıcaklıkların farkı olarak PET tahminlerinde hesaba katılmaktadır. Aylık gözlem verileriyle kullanıldığında ise söz konusu aydaki maksimum ve minimum sıcaklıkların yașandığı günler çalıșılan aydaki tüm günlerde geçerliymiș gibi PET tahminlerinde hesaplamalara katılmaktadır. Bu da aylık meteorolojik gözlem verileriyle $H S$ metodunun kullanılması durumunda dikkatli olunmasını, ayrıca bu yöntemin günlük veriler için türetildiği gerçeğinin hatırlanması gerektiğine ișaret etmektedir.

\section{SONUC̣LAR}

Bu çalıșmada, dünyanın birçok bölgesinde yaygın bir șekilde kullanılan ve güvenilir PET tahminleri yapan FAO56 PM metoduna Karaman ili özelinde daha az gözlem verisi gerektiren ve kullanımı daha basit alternatif PET tahmin yöntemlerinin neler olabileceği araștırılmıștır. Bu bağlamda önce FAO56 PM ile elde edilen günlük PET tahminleri aylığa çevrilmiș daha sonra bu değeler referans olarak kullanılarak TC, MK, JH, PT, BC, TH ve HS yöntemlerinden elde edilen aylık PET değerleriyle karșılaștırılmıștır. TC, FAO56 PM'ye en uyumlu tahmini yapan yöntem olmustur. HS metodu ise, Karaman ili aylık meteorolojik gözlem verileri kullanıldığında oldukça yüksek tahminler vermiștir. FAO56 PM ile HS yöntemleri arasında hesaplanan 54.02 mm'lik RMSE değeri bu kanıyı doğrulamaktadır. Buna göre karasal iklim özelliklerine sahip Karaman ili için yapılan aylık PET tahminlerinde, elde yeteri kadar ölçülmüș günlük meteorolojik gözlem verisinin olmaması durumunda TC gerektirdiği aylık ortalama nem, aylık ortalama sıcaklık ve aylık toplam global güneș radyasyonu verileriyle FAO56 PM'ye alternatif olarak ön plana çımaktadır. Turc metoduna yapılacak uygun bir kalibrasyonla, RMSE değerlerinin daha makul seviyelere düșürülebileceği açıktır. Bu durumun, Konya Kapalı Havzası'nda yer alan ve önemli tarımsal faaliyetlere ev sahipliği yapan Karaman ilinde aylık zaman adımlarında yapılacak tarımsal sulama planlamaları, su bütçesi, kuraklık ve iklim değișikliği çalıșmalarında yapılacak PET tahminleri için önemli bir kolaylık sağlayacağı inancı tașınmaktadır.

\section{KAYNAKLAR}

Abdulkareem JH, Abdulkadir A, Abdu N (2015). A review of different types of lysimeter used in solute transport studies. International Journal of Plant \& Soil Science, 8 (3): 1-14.
Akpolat A (2011). Mikrometeorolojik ve lizimetre yöntemleriyle belirlenen buğday bitki su tüketimlerinin karșılaștırılması. Yüksek lisans tezi, Çukurova Üniversitesi Fen Bilimleri Enstitüsü, Adana.

Aksu H, Arıkan A (2017). Satellite-based estimation of actual evapotranspiration in the Buyuk Menderes Basin, Turkey. Hydrology Research, 48(2): 559-570.

Alexandris S, Kerkides P, Liakatas A (2006). Daily reference evapotranspiration estimates by the "Copais" approach. Agricultural Water Management, 82(3), 371-386.

Alexandris S, Stricevic R, Petkovic S (2008). Comparative analysis of reference evapotranspiration from the surface of rainfed grass in central Serbia, calculated by six empirical methods against the Penman - Monteith formula. European Water, 21/22: 17-28.

Allen RG, Periera LS, Raes D, Smith M (1998). Crop evapotranspiration: guideline for computing crop water requirement. FAO Irrigation and Drainage Paper 56, p. 300.

Blaney HF, Criddle WD (1950). Determining water requirements in irrigated areas from climatological irrigation data. Technical Paper No. 96, US Department of Agriculture, Soil Conservation Service, Washington, D.C., p. 48.

Dingman SL (2008). Physical hydrology. Waveland Press, Inc., United States of America, p. 646.

Efthimiou N, Alexandris S, Karavitis C, Mamassis N (2013). Comparative analysis of reference evapotranspiration estimation between various methods and the FAO56 Penman-Monteith procedure. European Water, 42: 19-34.

FAO (Irrigation Water Manegement: Irrigation water needs, Chapter 3: Crop water needs). Available: http:// www.fao.org/docrep/s2022e/s2022e07.htm.

Fisher DK, Pringle III HC (2013). Evaluation of alternative methods for estimating reference evapotranspiration. Agricultural Sciences, 4(8A): 51-60.

Grismer ME, Orang M, Snyder R, Matyac R (2002). Pan evaporation to reference evapotranspiration conversion methods. Journal of Irrigation and Drainage Engineering, 128(3): 180-184.

Hamon WR (1961). Estimating potential evapotranspiration. Journal of Hydraulics Division-ASCE, 87(HY3): 107-120.

Jensen ME, Haise HR (1963). Estimating evapotranspiration from solar radiation. Journal of the Irrigation and Drainage Division-ASCE, 89(IR3):15-41.

Hargreaves GH (1975). Moisture availability and crop production. TRANSACTION of the ASAE: 18, 980-984.

Hargreaves GH, Samani ZA (1982). Estimation of potential evapotranspiration. Journal of the Irrigation and Drainage Division-ASCE, 108: 223-230.

Hargreaves GH., Samani ZA (1985). Reference Crop Evapotranspiration from Temperature. Applied Engineering in Agriculture, 1(2): 96-99.

Lingling Z, Jun $X$, Chong-Yu X, Zhonggen W, Leszek $S$ (2013). Evapotranspiration estimation methods in hydrological models. Journal of Geographical Sciences, 23 (2): 359-369. 
Lu J, Sun G, Mcnulty SG, Amatya DM (2005). A comparison of six potential evapotranspiration methods for regional use in the southeastern United States. Journal of the American Water Resources Association, 41 (3): 621-633.

Makkink GF (1957). Testing the Penman formula by means of lysimeters. Journal Institute of Water Engineering, $11(3): 277-288$.

Penman HL (1948). Natural evaporation from open water, bare soil and grass. Proceedings of the Royal Society of London. Series A. Mathematical and Physical Sciences, 193(1032), 120-145.

Priestley CHB, Taylor RJ (1972). On the assessment of the surface heat flux and evaporation using large-scale parameters. Monthly Weather Review, 100: 81-92.

Tabari H (2010). Evaluation of reference crop evapotranspiration equations in various climates. Water Resources Management, 24: 2311-2337.

Tukimat NNA, Harun S, Shadid S (2012). Comparison of different methods in estimating potential evapotranspiration at Muda Irrigation Scheme of Malaysia. Journal of Agriculture and Rural Development in the Tropics and Subtropics, 113(1): 77-85
Thornthwaite CW (1948). An approach toward a rational classification of climate. Geographical Review, 38: 55-94.

Trajkovic S (2007). Hargreaves versus Penman-Monteith under humid conditions. Journal of Irrigation and Drainage Engineering 133.1: 38-42.

Tuomenvirta $H$ (2001). Homogeneity adjustments of temperature and precipitation series- Finnish and Nordic data. International Journal of Climatology, 21: 495-506.

Turc L (1961). Water requirements assessment of irrigation, potential evapotranspiration: simplified and updated climatic formula. Annales Agronomiques, 12: 13-49.

Xu CY, Singh VP (2000). Evaluation and generalization of radiation-based methods for calculating evaporation. Hydrological Processes, 14: 339-349.

Zhai L, Feng O, Li O, Xu C (2010). Comparison and modification of equations for calculating evapotranspiration (ET) with data from Gansu Province, Northwest China. Irrigation and Drainage, 59 (4): 477-490.

Zhang K, Kimball JS, Nemani RR, Running SW (2010). A continuous satellite-derived global record of land surface evapotranspiration from 1983 to 2006. Water Resources Research, 46, W09522. 